\title{
KAJIAN LEARNING CONTENT MANAGEMENT SYSTEMS (LCMS) DALAM KERANGKA DISAIN PEMBELAJARAN
}

\author{
Oleh: Dewi Salma Prawiradilaga *)
}

\section{Abstract}

The article is about a descriptive finding on the function of an LCMS used by the official website of the Department of Curriculum and Educational Technology, Faculty of Education, State University of Jakarta, www.courses.web-bali.net. Based on the observation, there are some principles that may be applied in uploading course content. They are topic analysis and message design principles which should intensively be applied during developing and structuring learning objects in a learning path. Chunk is the main concept in content development. Regarding copyright issue, all parties should respect to those who write or produce creative works accessible through online.

Keywords: Topic analysis, LCMS (learning content management systems), message design, learning objects, learning paths, copyright.

\section{A. PENDAHULUAN}

\section{Pengantar}

Pemanfaatan jaringan telekomunikasi dan komputer sudah menjadi bagian dari kehidupan di Jakarta. Jurusan Kurikulum dan Teknologi Pendidikan, Fakultas IImu Pendidikan Universitas Negeri Jakarta tidak luput dari terjangan angin globalisasi ini. Tulisan ini merupakan upaya memberdayakan segala potensi yang dapat terjangkau oleh jurusan KTP yang (kebetulan) secara geografis berada di ibukota Indonesia. Websites resmi jurusan, www.web-bali.net dengan domain perkuliahan www.courses.webbali.net masih under construction. Berdasarkan pengamatan penulis, masih banyak lembaga pendidikan yang menyajikan online learning dengan mengirimkan materi ajar melalui internet. Dalam pandangan penulis, website yang disediakan oleh mereka tidak lebih dari menawarkan jasa kurir untuk pengiriman materi ajar. Bahasan mengenai LCMS yang berbeda dengan sudut pandang sebagai disainer pembelajaran ini menjadi misi utama yang ingin disampaikan oleh penulis.

\section{Latar Belakang}

Globalisasi dan munculnya jaringan luas seperti world wide web sebagai inovasi yang mengubah paradigma di berbagai bidang, termasuk dalam dunia pendidikan. Belajar jarak jauh (distance learning) serta e-learning cepat sekali dikenal. Tawaran untuk mengikuti proses

*) Dewi Salma Prawiradilaga adalah dosen Jurusan Kurikulum dan Teknologi Pendidikan, Fakultas IImu Pendidikan - UNJ, mengajar matakuliah Disain Pembelajaran serta Konsentrasi Teknologi Kinerja. 
belajar dengan kedua model ini dari berbagai lembaga pendidikan di dunia tak terhitung jumlahnya. Kemudahankemudahan di antaranya tidak ada ketentuan mengikuti jadwal, serta lokasi belajar yang disesuaikan dengan kemampuan peserta didik mampu menjaring peminat. Dengan mengakses internet yang terjangkau di kota besar di Indonesia, maka model belajar jarak jauh dan e-learning menjadi alternatif untuk memperoleh dan meningkatkan pendidikan. Jenjang yang ditempuhpun beragam, mulai dari kursus singkat sampai dengan program gelar S3.

Di lain pihak, kemandirian peserta didik, tanpa tergantung kehadiran seorang guru, menjadi tuntutan yang lumrah dalam proses belajar tersebut. Untuk itu, salah satu aspek yang menjadi bagian penting adalah penyampaian materi atau isi dari suatu mata pelajaran atau matakuliah yang diakses. Pengolahan materi untuk belajar mandiri memerlukan rancangan khusus, Kaidah belajar, pembelajaran, disain pembelajaran serta disain pesan merupakan persyaratan yang harus dipenuhi. Dengan demikian, peserta didik dapat mencerna materi (online) lebih baik dan lebih mudah lagi.

Pengolahan materi ajar menggunakan piranti lunak yang termasuk dalam kategori course management yaitu learning content management systems (LCMS). Fungsi-fungsi yang ditawarkan oleh LCMS tersebut ternyata masih belum optimal serta belum terungkap makna dari setiap model sajian. Terlebih pengajar masih banyak belum terbiasa mengolah materi secara online. Padahal pilihan LCMS baik yang diunduh gratis atau dibeli dari produsen tertentu sangat banyak. Setiap LCMS memiliki sifat dan kelebihan tersendiri. Menciptakan virtual learning environment yang sesuai dan benar merupakan tantangan tersendiri bagi pengajar dan para disainer pembelajaran di era digital ini.

\section{B. KAJIAN LEARNING CONTENT MANAGEMENT SYSTEMS (LCMS) DALAM KERANGKA DISAIN PEMBELAJARAN}

\section{Ikhtisar Au thoring Tools Antara LMS dan LCMS}

Kemajuan teknologi digital berikut piranti aplikasi sangat pesat. Open source banyak menyediakan piranti lunak untuk berbagai bidang dan profesi, termasuk di dalamnya bidang kependidikan dan pembelajaran dalam format authoring tools. Peran authoring tools dalam pendidikan dan pembelajaran bagi Dabbagh \& Bannan-Ritland yakni, "Authoring tools are softwares that enable instructional designers, teachers, and learners to design interactive multimedia and hypermedia learning environments without knowledge of programming languages" (hal. 273). Untuk itu, course management disediakan agar para pengguna dapat mengunduh kemudian memanfaatkannya bagi penyelenggaraan model e-learning. Course management itu sendiri sekarang ini dikenal mempunyai dua kategori besar, yaitu learning management systems (LMS) serta learning content management systems (LCMS).

Perdebatan antara pilihan atas LMS ataukah LCMS sudah beberapa lama muncul ke permukaan (lihat: Dabbagh \& Bannan-Ritland, hal. 275; Greenberg; Chapman, 2001; Robbins, 2002; Mortimer, 2002; Shaw, 2007). Perbedaan pendapat mengerucut mengacu pada keberadaan LMS serta LCMS. Bagi Dabbagh \& Bannan-Ritland; Robins, serta Mortimer, LMS diciptakan sebelum LCMS. LMS adalah generasi pendahulu, sedangkan LCMS muncul dan diciptakan karena para ahli berniat menyempurnakan LMS yang sudah lebih dulu beredar. Pendapat berbeda dikemukakan oleh Greenberg. Baginya, LMS berlainan fungsi dengan LCMS (lihat : kutipan tabel dari Greenberg). Namun, fungsi keduanya dianggap lebih baik dan lebih optimal lagi jika bersinergi dalam penyelenggaraan proses belajar. 
Pendapat ini didukung oleh Chapman dan Shaw. Tulisan ini tidak akan menitikberatkan perbedaan pendapat tadi, namun cenderung membahas pemanfaatan LCMS untuk penyelenggaraan perkuliahan.

Untuk bidang teknologi pembelajaran, pilihan menjadi lebih mudah jika kita merujuk pada definisi-definisi tentang teknologi pendidikan dan teknologi pembelajaran dari organisasi profesi $A E C T$. Benang merah dari rumusan teknologi pendidikan dan teknologi pembelajaran mulai dari definisi tahun 1977, 1994 serta 2004 (lihat : Januszewski \& Molenda, eds., 2008) adalah proses belajar. Definisi AECT tahun 2004 menyebutkan teknologi pendidikan adalah untuk memfasilitasi proses belajar di pendidikan formal serta meningkatkan mutu kinerja di organisasi. Tentu saja LCMS dimanfaatkan untuk dua kepentingan utama tadi.

Dari dua jenis course management (LMS dan LCMS) yang ditawarkan, LCMS dianggap pilihan yang tepat. LCMS berkaitan langsung dengan proses belajar dan peningkatan mutu kinerja. yaitu penyajian materi ajar dengan menerapkan prinsip disain pembelajaran. Bahasan selanjutnya menegaskan alasan pemanfaatan LCMS untuk menciptakan proses belajar.

\begin{tabular}{|l|l|l|}
\hline & \multicolumn{1}{|c|}{ LMS } & \multicolumn{1}{|c|}{ LCMS } \\
\hline Who benefits & All learners; organization. & $\begin{array}{l}\text { Content developers; } \\
\text { learners who need } \\
\text { personalized content. }\end{array}$ \\
\hline $\begin{array}{l}\text { Provide primary } \\
\text { management of }\end{array}$ & $\begin{array}{l}\text { Learner performance; learning } \\
\text { requirements; learning } \\
\text { programs and planning }\end{array}$ & Learning content \\
\hline $\begin{array}{l}\text { Manages e-learning } \\
\text { Manages traditional forms of } \\
\text { training such as instructor-led }\end{array}$ & Yes & Yes \\
\hline Tracks of results & Yes & No \\
\hline $\begin{array}{l}\text { Supports learner } \\
\text { collaboration }\end{array}$ & Yes & Yes \\
\hline $\begin{array}{l}\text { Includes learner profile } \\
\text { management }\end{array}$ & Yes & Yes \\
\hline $\begin{array}{l}\text { Allows HR and ERP Systems } \\
\text { to share learner data }\end{array}$ & Yes & No \\
\hline $\begin{array}{l}\text { Schedules events } \\
\text { Offers competency mapping } \\
\text { skill gap analysis }\end{array}$ & Yes & No \\
\hline $\begin{array}{l}\text { Includes registration, prere- } \\
\text { quisite screening, and } \\
\text { cancellation notification }\end{array}$ & Yes & No \\
\hline $\begin{array}{l}\text { Creates test questions and } \\
\text { test administration }\end{array}$ & Yes & No \\
\hline $\begin{array}{l}\text { Support dynamic } \\
\text { pretesting and adaptive } \\
\text { learning }\end{array}$ & No & No \\
\hline Support content creation & No & Yes \\
\hline $\begin{array}{l}\text { Organize reusable content } \\
\text { manage conteit creation } \\
\text { progress }\end{array}$ & Yes & No \\
\hline $\begin{array}{l}\text { Develops content } \\
\text { navigation control and user } \\
\text { interface }\end{array}$ & No & Yes \\
\hline
\end{tabular}

Gambar 1. Tabel Perbandingan LMS dan LCMS menurut Greenberg 


\section{Perbandingan fungsi LMS dan LCMS}

Walaupun tulisaan ini tidak membahas perbedaan pendapat mengenai LMS dan LCMS, namun ada baiknya pendapat Greenberg di bawah ini dikaji agar alasan pemanfaatan LCMS untuk menciptakan proses belajar lebih kukuh.

\section{Learning Content Management System (LCMS) \\ Pengertian LCMS}

Shaw yang diwawancarai oleh Checkpoint E-Learning Journal menyatakan bahwa "An LCMS is an application designed to facilitate the creation or capture, management, and transfer or distribution of content designed for learning or performance support. Content is created using an object model". Sedangkan Greenberg mengutip rumusan IDC untuk LCMS dengan pernyataan, "an LCMS as a system that creates, stores, assembles and delivers personalized e-learning content in the form of learning objects".

Chapman juga menyatakan hal yang serupa dengan kedua pendapat sebelumnya. la merumuskan, "An LCMS is a multi-user environment where learning developers can create, store, reuse, manage, and deliver digital learning content from a central object repository". Ketiga pendapat tadi bermuara pada penyajian isi atau materi ajar secara digital dalam suatu bentuk khusus dengan istilah learning object. Materi tersebut dibuat, disimpan, dipelajari atau didaur-ulang/diperbaiki dan dapat diakses oleh peserta didik secara online.

\section{Kriteria}

Selanjutnya, Greenberg dalam makalah yang sama menyebutkan beberapa kriteria yang seharusnya dipenuhi oleh suatu LCMS. Kriteria tersebut adalah:

- learning object repository: tempat penyimpanan dan pengelolaan isi/ bahasan dari suatu matakuliah.

- automated authoring application: fungsi-fungsi dalam alur belajar yang mempermudah ahli materi/pengajar/ disainer pembelajaran untuk menyusun materi atau storyboards sesuai kebutuhan.

- dynamic delivery interface: adanya fungsi (manajemen) pembelajaran seperti asesmen belajar, umpan balik, kemudahan akses sumber belajar, dst.

- administrative application: fungsi manajemen pendidikan yang memadai, yang mencakup aspek laporan perkembangan belajar, matakuliah yang menjadi prasyarat, kehadiran secara maya, dsb.

Senada dengan Greenberg, Chapman menyatakan bahwa suatu LCMS sebaiknya memiliki beberapa kekhususan yakni:

- memiliki authoring tools untuk menciptakan learning objects dalam suatu repository.

- kemampuan untuk merangkai dan mengkonsolidasikan learning objects dalam alur belajar (learning paths) yang dinamis, dikembangkan sesuai kebutuhan atau tergantung disainer pembelajaran

- mampu menelusuri siapa yang belajar apa (tracks who takes what).

Merujuk kedua kutipan tadi, kesimpulan yang dapat dirumuskan terkait dengan kriteria LCMS yang harus mempunyai (1) repository, yaitu pusat data untuk menyimpan, mengubah, menambah, materi /isi pelajaran/matakuliah; (2) bentuk isi dalam alur belajar (learning path) yang tersusun dari learning objects, (3) authoring tools yang dapat digunakan untuk menciptakan learning objects yang dinamis dan dapat didaurulang; serta (4) kemampuan administratif untuk menelusuri laju belajar, hasil asesmen, menyimpan dokumen yang diperlukan, jadwal, dan sebagainya. Atau sebagaian besar fungsi LMS untuk mengelola proses belajar dan pembelajaran.

Learning path (alur belajar):

Alur belajar sebagai bagian inti dari LCMS merupakan 'Iahan' dan 'pintu' yang menjadi keistimewaan suatu LCMS 
dalam rangka penyajian materi ajar. Pandangan teknologi pendidikan/ pembelajaran yang mementingkan proses belajar dikaji secara mendalam demi penyajian materi yang terbaik agar peserta didik dengan mudah dan 'nyaman' dapat mempelajari materi tersebut. Tozman menyebutkan bahwa alur belajar adalah skema belajar yang berisi materi ajar terstruktur dan dapat diikuti oleh pengguna dengan mudah.

Penyajian materi dalam alur belajar memerlukan kemampuan dalam bidang disain pesan, yaitu sewaktu memilih, memilah materi untuk dituliskan dalam alur belajar tersebut. Selain itu, penulis atau pengajar harus menterjemahkan situasi belajar nyata ke dalam situasi belajar maya, yaitu dalam kerangka menciptakan lingkungan belajar maya (virtual learning environment) agar interaksi belajar, synchronous atau asynchoronous, terjadi dan lancar.

\section{Learning objects}

Learning objectsecara singkat adalah penggalan materi yang disajikan dalam satu alur belajar. Chapman merumuskan learning object sebagai, 'A standalone learning. May have chipped out of a legacy course". Istilah chunk (penggalan) menunjukkan betapa kecil cakupan isi dalam suatu learning object. Terkadang, learning object juga diibaratkan sebesar butir gula pasir (granulation). Ini menunjukkan betapa khusus dan kecil cakupan suatu learning object. Jumlah learning object dalam satu alur belajar tidak tertentu, tergantung dari pencipta alur belajar tersebut.

Secara gamblang, suatu rangkaian film berbingkai dapat diubah dan dicantumkan dalam suatu alur belajar sebagai suatu learning object. Begitu pula kalimat, rumus, pernyataan, atau asesmen belajar yang digunakan untuk mengukur penguasaan materi yang sedang dipelajari dapat dibentuk sebagai learning objects. Rangkaian learning objects yang ada pada suatu alur belajar dapat disajikan dalam pdf, gambar penyajian, wordprocessing, dan sebagainya.
Chapman, yang dikutip oleh Mortimer, menyebutkan dua model learning objects yang dapat dimanfaatkan untuk pembelajaran, yakni bersifat preskriptif dan adaptif. Learning object yang bersifat preskriptif menyediakan slot atau lahan untuk diisi oleh ahli materi secara terstruktur. Penyajian materi disesuaikan dan mengikuti pola yang telah tersedia. Pola penyajian biasanya jauh lebih lengkap dibandingkan dengan pola adaptive learning object. Sedangkan adaptive learning object memiliki pola yang tidak lengkap namun lebih luwes untuk 'dibentuk' dan disesuaikan dengan keinginan ahli materi. Ketidaklengkapan lahan biasanya diimbangi dengan perangkat yang dapat dimanfaatkan secara optimal untuk menyusun isi/ materi ajar.

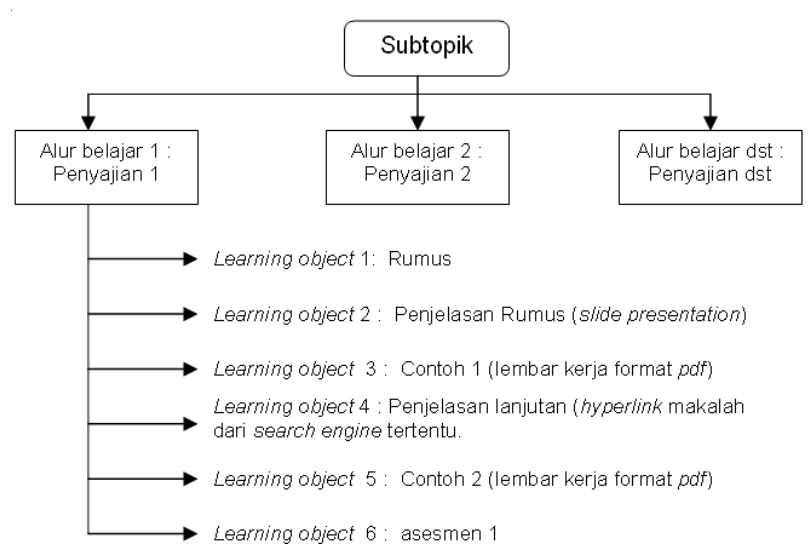

Gambar 2 . Ilustrasi cakupan learning object dalam suatu alur belajar.

\section{Ikhtisar Disain Pembelajaran Konsep analisis topik}

Jika LCMS mengenalkan istilah chunk (penggalan), dalam konsep disain pembelajaran istilah itu disebut dengan analisis topik. Konsep analisis topik diperkenalkan oleh Kemp, dkk, sebagai salah satu pola pemikiran dalam disain pembelajaran (Prawiradilaga, 2007)

Berbeda dengan pendekatan sistemik yang dirumuskan sebagai ADDIE, analisis topik memulai disain pembelajaran tidak dengan merancang situasi belajar 
melainkan dengan mengkaji mata ajar. Kajian ini dimulai dengan melakukan analisis peserta didik dan mengembangkan dan memilah mata ajar menjadi subbagian yang lebih kecil namun mendalam sebagaimana digambarkan dalam pola konvensional analisis materi berikut ini. Alur analisis ini biasa dilakukan oleh seorang ahli materi atau subject matter expert. Dalam ilmu teknologi pendidikan, ahli materi tidak lain adalah pengajar atau guru. IImu yang dimiliki atau latar belakang pendidikan yang menjadi tumpuan profesi mengajar inilah yang dijadikan modal dasar bagi konsep analisis topik. Biasanya semakin kuat latar belakang keilmua seorang pengajar, semakin rumit dan mendalam analisis topik yang dihasilkan. Untuk membatasinya, analisis karakteristik akademik peserta didik, jenjang pendidikan serta tujuan pembelajaran dapat dijadikan acuan untuk melaksanakan analisis topik. Tatakerja analisis topik divisualkan dalam Gambar 4.

Gambar 4 : Skema analisis topik menurut Kemp, dkk (dalam Prawiradilaga, ibid).

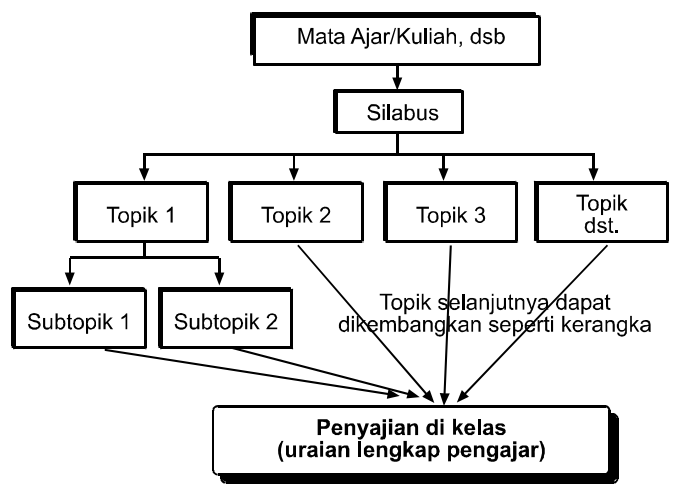

Gambar 5.

Pola Konvensional Analisis Isi

Berlandaskan dua konsep tersebut di atas, maka sistem pembelajaran yang dikembangkan menurut analisis topik terdiri atas subsistem (komponen):

- silabus, materi ajar (topik dan subtopik) sebagaimana rincian pada Gambar 5;

- tujuan pembelajaran, dirumuskan dalam format kompetensi atau kemampuan yang diharapkan dari peserta didik sebagai hasil belajar;

- analisis materi ajar yang dilaksanakan dengan rincian jelas dan menyeluruh, yaitu analisis yang dilaksanakan sampai dengan komponen terkecil dan sangat khusus;

- program pembelajaran dan penyajian materi di kelas, yaitu proses penyampaian pesan atau kegiatan tatap muka yang harus diikuti oleh peserta didik atas bimbingan pengajar;

- evaluasi pembelajaran yang mencakup penilaian atas kegiatan pembelajaran serta penilaian terhadap tingkat penguasaan kemampuan atau kemampuan peserta didik (asesmen belajar),; serta

- perbaikan dilakukan terhadap program pembelajaran agar segala keterbatasan dan kekurangan di masa yang akan datang dapat teratasi dan tidak terjadi lagi.

\section{Alur Penyajian}

Analisis topik tadi mencakup isi secara makro. Untuk mengembangkan isi kedalam LCMS, masih diperlukan saju jenjang lagi yaitu analisis topik secara mikro atau yang dikenal sebagai alur penyajian(lihat: Simonson, dkk, 2006: 136--140). Alur penyajian merupakan pola penyajian materi ajar untuk media teks. Pemilihan alur penyajian ditentukan terutama oleh:

- sifat materi ajar, misalnya materi yang bersifat lanjutan memerlukan kemampuan prasyarat. Kemampuan prasyarat menjadi bagian skema alur penyajian.

- laju belajar peserta didik dapat menentukan apakah alur penyajian tersebut harus menyediakan pengayaan, atau jika peserta didik termasuk dalam kategori cepat, apakah alur yang lebih tinggi sudah tersedia.

Alur penyajian konvensional dan mikro telah dikenal sejak dulu; diterapkan untuk pengembangan pembelajaran yang 
diindividukan atau programed instruction. Kedua alur penyajian yang dimaksud adalah alur linear dan bercabang (branched). Masing-masing alur berperan beda dalam proses belajar seseorang. Alur linear menyajikan materi secara berurutan, dengan sendirinya materi tersebut dipelajari oleh peserta didik berurutan pula. Setiap penggalan materi menjadi kemampuan prasyarat bagi penggalan selanjutnya. Penggalan matari lanjutan dianggap tidak dapat dikuasai oleh peserta didik jika penggalan sebelumnya (yang dianggap lebih mudah) belum selesai atau belum dikuasai oleh peserta didik.

Alur bercabang memberi alternatif lain. Jika suatu materi yang dianggap menjadi prasyarat namun belum dapat dipahami peserta didik, maka peserta didik dapat mengkaji materi alternatif. Sifat materi alternatif adalah setara dengan materi yang digantikannya. Hanya, model dan tehnik penyajiannya yang berbeda dan diprediksikan lebih memadai bagi peserta didik tersebut. Kedua alur penyajian dapat diterapkan dalam satu alur belajar untuk suatu LCMS.

Alur penyajian keempat, yaitu model selfdirected, yang menitikberatkan pada kemampuan dan kemauan peserta didik untuk memantany dan mengelola proses

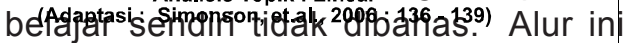
sancat sulit diterankan Trarena

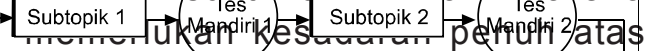

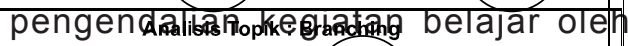
peserta didili iturgendifibs

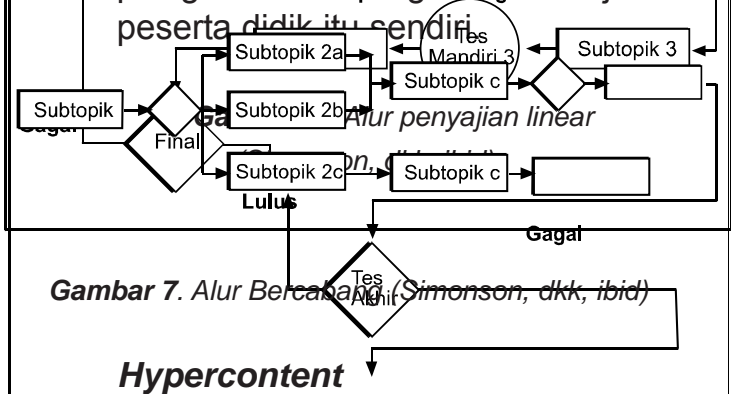

Pola hypercontent merupakan inovasi yang dipengaruhi oleh kemutakhiran teknologi digital yang mampu menyediakan hypermedia. Jika dalam dua pola konvensional sebelumnya peserta didik diatur proses belajarnya, maka pola hypercontent menyerahkan pengaturan alur belajar kepada peserta didik itu sendiri. Penyajian hypercontent mencerminkan penerapan paradigma learner-centered secara digital. Setiap bahasan telah dilengkapi seluruh komponen yang termasuk dalam sistem pembelajaran, seperti tujuan pembelajaran serta tugas dan asesmen terkait. Namun, untuk memulai atau mengakhiri, atau laju belajar diserahkan sepenuhnya kepada peserta didik. Materi yang bersifat hypercontent sesuai bagi peserta didik yang self-directed. Karakteristik peserta didik, sifat materi ajar serta tingkat kesulitan, kendala teknologi dan aspek teknis sebaiknya dipertimbangkan dalam menentukan alur penyajian materi.

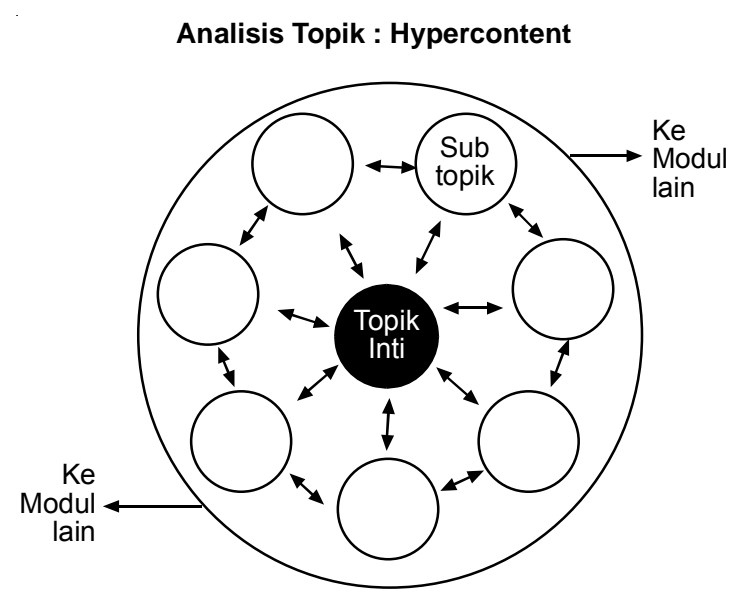

Gambar 8. Alur Acak atau Hypercontent (Simonson, dkk, ibid)

\section{LCMS dalam konteks Disain Pembelajaran}

- Makna LCMS dalam konteks Pembelajaran

Hampir setiap LCMS memiliki kemiripan satu sama lain. Namun, pada dasarnya kekhasan dan kreatifitas pengguna saat mengembangkan materi akan menjadikan tampilan suatu LCMS menjadi berbeda satu sama lain. Untuk itu, langkah yang paling awal dalam pemanfaatan LCMS adalah memaknai authoring tools (perangkat menulis) yang ada dalam kerangka pembelajaran. Sebagai contoh, perangkat media center dialihkan sebagai sumber belajar; course description sebagai kontrak 
perkuliahan atau silabus, users menjadi mahasiswa, assignment adalah tugas perkuliahan.

Selanjutnya, jika proses memaknai terus berlanjut, secara perlahanlahan sifat pembelajaran yang nyata dapat dialihkan ke dalam situasi pembelajaran maya (virtual learning environment). Dengan demikian, secara bertahap seluruh perangkat menulis beralih fungsi menjadi subsistem pembelajaran. Memaknai perangkat menulis adalah pekerjaan besar pertama yang harus 'ditangani' oleh seorang disainer pembelajaran atau pengajar dalam suatu lingkungan belajar maya. Dengan kata lain, pengajar dengan kesadaran tinggi harus mengubah pola pikir sendiri serta mengembangkan daya kreatifitasnya untuk menciptakan pembelajaran maya.

- $\quad$ Analisis Topik dalam LCMS

Dibalik cakupannya yang sangat kecil dan khusus, ternyata membuat suatu learning object adalah pekerjaan besar, sangat penting, dan tidak bisa diwakilkan. Penyusunan learning object adalah pekerjaan yang besar. Awalnya, topik dianalisis dengan memilah-milah sebagaimana diilustrasikan pada Gambar 4 dan Gambar 2. Setelah itu, hasil pemilahan dikembangkan dalam bentuk peta informasi yang lengkap. Pemilihan alur penyajian ditentukan setelah peta informasi selesai. Setelah itu, penyusunan learning object secara online dapat dimulai. Sambil menyusun, dengan mempertimbang-kan faktor peserta didik, tujuan pembelajaran dan situasi yang diharapkan, paradigma pembelajaran sekaligus dapat ditentukan.

Learning object menjadi salah satu ciri baik atau buruknya penyajian materi online. Penyusunan learning object menjadi rangkaian materi ajar yang dapat diserap dan 'membelajarkan' adalah bukti kepiawaian seorang disainer pembelajaran atau pengajar. Tugas inilah yang membedakan penyajian materi di ruang kelas dan dalam dunia maya. Selama ini, program e-learning banyak dikembangkan dengan tehnik mengubah format penyajian di kelas langsung ke format elektronik. Penerapan tehnik seperti ini sebenarnya hanyalah memfungsikan jaringan global sebagai kurir pengiriman materi ajar bukan untuk menciptakan proses belajar atau pembelajaran.

- Penerapan teori belajar dan pembelajaran.

Tidak hanya analisis topik dengan tehnik penggalan saja yang digunakan dalam LCMS. Komponen lain seperti adanya kemungkinan hyperlink atau mengukur hasil belajar secara langsung menjadikan LCMS dapat dimaknai dengan teori pembelajaran dan teori belajar lainnya. Konsep sistem tetap dapat diterapkan secara terus menerus untuk penyajian online. Selain itu, strategi pembelajaran dengan metode diskusi dapat dilakukan dengan cara mengaktifkan interaksi antar mahasiswa (users) dengan mengolah chatting menjadi diskusi. Secara teknis, perangkat menulis yang umumnya memiliki icons yang sama untuk digunakan menciptakan pola belajar dan pembelajaran.

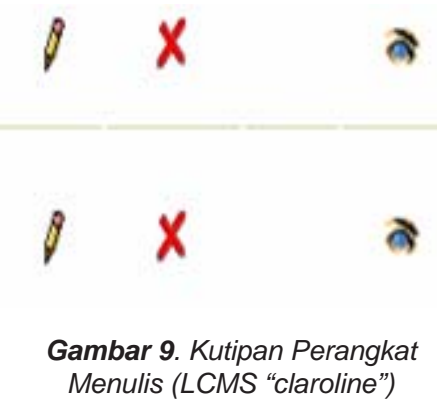

Gambar pensil mewakili kegiatan menulis, artinya jika gambar pensil diclick, para pengguna dapat menulis, mengganti, memodifikasi learning object. Dalam hal ini, materi ajar dapat 
digunakan. Sebaliknya, jika gambar silang diclick maka learning object dapat dihapus. Dan inilah salah satu kelebihan learning object yaitu dapat didaurulang (reusable). Jika gambar mata yang dipilih, maka konteks yang terkandung di dalamnya adalah paradigma pendidikan. Pengajar yang sengaja menutup atau membuka gambar mata sesuai dengan pengamatannya atas proses belajar, maka ia menerapkan prinsip teachercentered. Namun jika ia membiarkan seluruh mata terbuka untuk seluruh learning object, berarti dia menerapkan learner-centered. Membuka dan menutup icon mata berarti membuka atau menutup akses bagi peserta didik untukmengkaji materi online. Masih banyak lagi prinsip pembelajaran dan disain pembelajaran yang dapat dikaji dan diterapkan dalam LCMS.

- Disain Pesan

Penyusunan learning objects yang berlandaskan prinsip penggalan mengandung aspek disain pesan diterapkan dalam kerangka :

- pemanfaatan potensi hypermedia yang dapat menyajikan learning object dalam format interaktif,

- pemanfaatan gambar penyajian dalam berbagai format (powerpoint, pdf, ds);

- penyusunan dan pemilihan kalimat yang efektif dan mudah dicerna serta tehnik penggalan atau chunk,

- penggunakan contoh-contoh yang tepat sebagai learning object,

- menghidupkan seluruh potensi teknologi yang terkandung dalam LCMS untuk penyajian pesan atau materi ajar.

Prinsip umum disain pesan (Fleming \& Levie, 1978) yang terkandung dalam LCMS diantaranya untuk persepsi yang berbunyi, "(1.3). Perception is organized. We do not generally perceive chaotic arrays of different brightness, colors, temperatures, and noises. Rather, we perceptually construct relationships, groupings, objects, words, and people". Persepsi dalam konteks disain pesan merupakan aspek utama belajar. Persepsi adalah kemampuan seseorang untuk mencerna segala sesuatu yang berada di lingkungan melalui indera, termasuk lingkungan untuk penyelenggaraan proses belajar.

Terkait dengan sifat penyajian secara digital yang termasuk media teks (Smaldino, dkk, 2008: 7), prinsip disain pesan tersebut adalah "(1.27). Digital messages (words, numbers) can be perceived through either auditory or visual modalities or both. Iconic messages can only be perceived through vision". Terkait dengan prinsip penggalan, prinsip disain pesan yang diterapkan adalah, "(1.32). Perceivers partition the avalaible information into as large or as appropriate an item size as the stimulus and their experience and intention allow. They are said to chunk or cluster or group".

\section{PENERAPAN MODEL E-LEARNING PADA JURUSAN KURIKULUM DAN TEKNOLOGI PENDIDIKAN, FAKULTAS ILMU PENDIDIKAN, UNIVERSITAS NEGERI JAKARTA : LESSON LEARNED.}

Jurusan KTP FIP UNJ sedang mengembangkan model belajar hibrida yang mungkin dapat diterapkan dalam suatu universitas konvensional. Model belajar hibrida yang dimaksud adalah penerapan KBM sebagaimana universitas konvensional serta memanfaatkan potensi komputer dan jaringan global sebagai web-based learning bagi penyajian beberapa topik atau bahasan kuliah, terutama yang terkait dengan aspek kognitif. Adapun official website jurusan adalah www.web-bali.net dengan domain untuk perkuliahan : www.courses.webbali.net. Sedangkan blogs www.tpers.net serta www.teknologipendidikan.net tetap dipertahankan sebagai sarana interaksi antar 
mahasiswa dan siapa saja yang berminat urun pendapat tentang teknologi pendidikan.

Beberapa hal yang dapat diuraikan selama proses pengembangan ini sedang berlangsung diantaranya adalah:

\section{Disain Lingkungan Belajar Maya (Design of Virtual Learning Environment)}

Seperti telah dijelaskan sebelumnya, Jurusan KTP sedang mengembangkan pola belajar hibrida. Tahap awal adalah membangun model e-learning dengan menerapkan LCMS claroline yang diunduh secara bebas dan gratis. Penjelasan berikut menggambarkan langkah awal yaitu memberi makna LCMS claroline dalam kerangka disain pembelajaran. Langkah-langkah yang dilakukan yaitu :

- mengkaji platform LCMS claroline mengenai sifat dan perangkat yang ada di dalamnya dengan acuan teori LCMS dari berbagai sumber. Hasil kajian menunjukkan bahwa platform tersebut bersifat adaptif.

- mengujikan tingkat adaptif platform dengan cara mencoba mengisi platform tersebut dengan salah satu matakuliah yang ditawarkan di jurusan, yaitu matakuliah Disain Pembelajaran (untuk mahasiswa baru). Alasan mendasar pemilihan matakuliah Disain Pembelajaran ini dengan prediksi bahwa peserta didiknya adalah mahasiswa baru yang dipersiapkan untuk sosialisasi model belajar hibrida.

Aspek adaptif dipenuhi dengan beberapa kekhususan seperti bagian Course Description melalui visualisasi berikut:

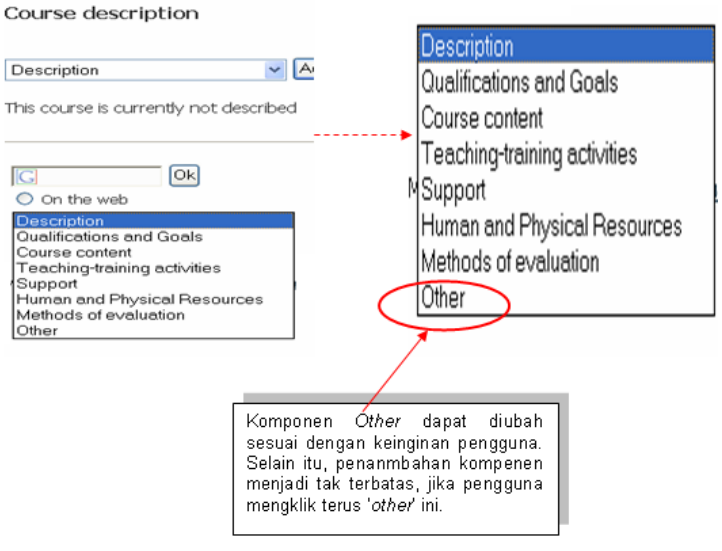

Gambar 10.

Kutipan Course Description dari platform Claroline

Aspek adaptif dalam bagian Learning Path List diilustrasikan seperti di halaman berikut.

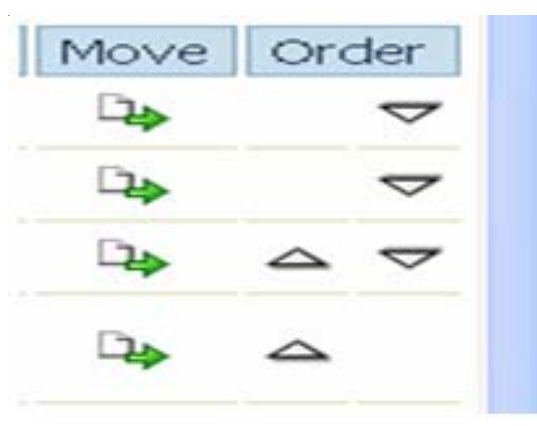

\section{Gambar 11.}

Kutipan Learning Path Admin

Icon Move dimanfaatkan untuk penjenjangan materi ajar dalam rangka pemilahan topik menjadi learning object. Jika icon ini dipilih maka akan muncul panel yang menanyakan root atau daftar penggalan materi yang sudah ditulis. Dengan demikian, materi ajar dapat dipilah menjadi lebih tinggi, atau lebih rendah sesuai dengan keinginan pengguna. Icon Order digunakan untuk menggeser atau memindahkan urutan learning object dalam satu jenjang yang sama. 


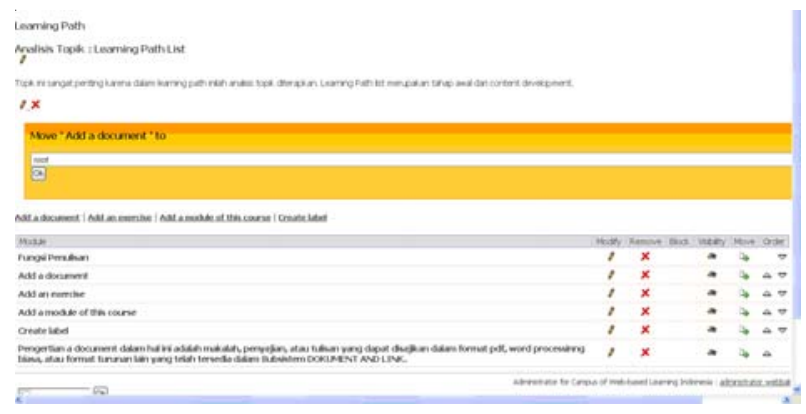

Gambar 12.

Panel untuk Menentukan Jenjang Materi

- memaknai platform tersebut dalam konteks pembelajaran. Sebagai contoh, course description tadi diumpamakan sebagai sistem pembelajaran.

Authoring tools ini tersedia di halaman muka dari LCMS Claroline. Selanjutnya semua perangkat ini 'dianggap' sebagai learning technologies yang akan dimanfaatkan untuk menciptakan proses belajar maya. Secara khusus, perangkat kemudian dianggap sebagai suprasistem pembelajaran.

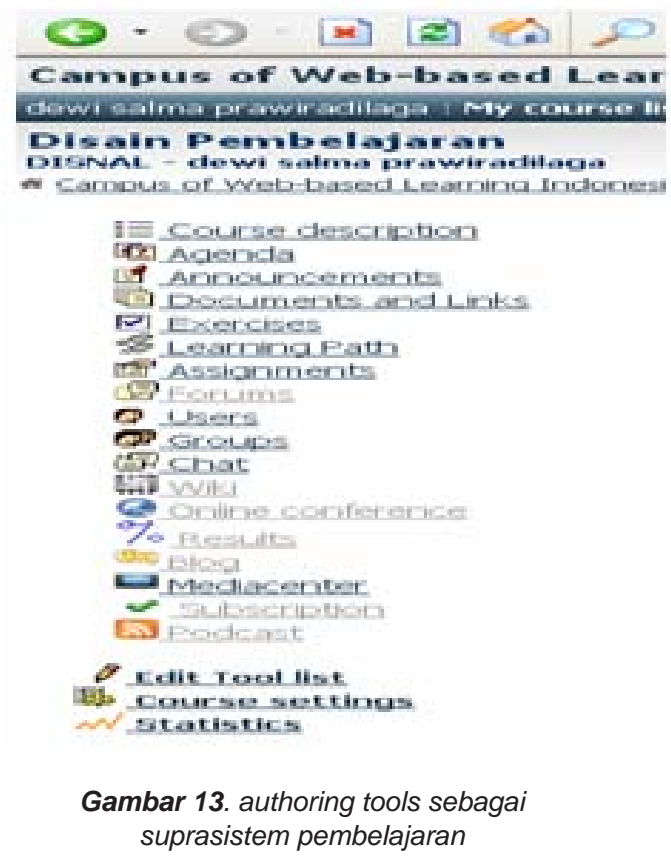

\section{Pengembangan Isi (Content} Development)

Pengembangan isi dilakukan dengan mengacu pada beberapa prinsip dasar sebagai berikut:

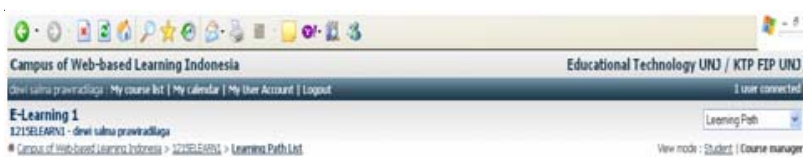

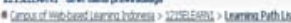

Leming Path List

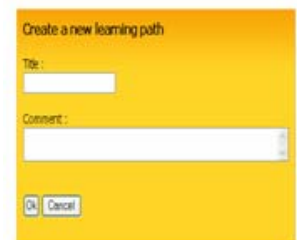

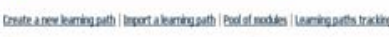

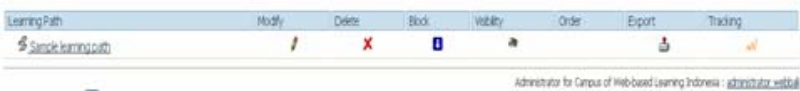

a. Menyusun alur belajar dalam skema disain pembelajaran dengan tehnik analis topik dan tipografi (lihat: Morrison, Ross, \& Kemp, 2007: 77 dan 176-180). Setiap subtopik dijadikan sebagai satu alur belajar. Penerapannya seperti:

Matakuliah : Disain Pembelajaran

Topik : Peran dan Kedudukan

Disain Pembelajaran dalam TP

Prinsip Dasar Disain

Pembelajaran, Model KBM PROGRAM dst

Subtopik : (diamblil dari salah satu topik secara acak) Model

KBM

PROGRAM terdiri atas

1. Model KBM dan fungsinya.

a. Perumusan Tujuan Pembelajaran

b. dst.

Gambar 14. Panel untuk Penyusunan Alur Belajar

b. Menerapkan prinsip disain pesan sebagai rujukan dalam penyusunan learning object. Alur penyajian yang dipilih bersifat linear. Sedangkan prinsip disain pesan dari Fleming \& Levie (op.cit) yang dapat digunakan sebagai acuan menentukan penggalan (chunk) selain prinsip yang telah dijelaskan sebelumnya diantaranya adalah:

- (1.33). The better organized or patterened a message is perceived to be, the more 
information we can receive (and process) at one time.

- (1.35). For verbal materials in a single channel situations, the more difficult or complex the verbal material, the greater the perceptual advantage of the visual channel (printed) over the auditory (spoken).

- (2.2.) Learning is to associate or relate two or more objects or events (stimuli and/or responses) is facilitated where they occur or are encountered in contiguity, i.e. close together in time or space.

- (2.26). Where material to be learned is organized and that organization is apparent to the learner, acquisition will be facilitated.

- (3.3). Abstract concepts can be learned from a variety of verbal structures, e.g. definitions (including criterial attributes), sentence contexts, described examples, and synonyms.

- (3.5). Choose both examples and non examples for instruction.

- (3.14). Presenting a definition as a list of criterial attributes can facilitate concept acquisition over presenting it in typical sentence form.

Begitu pula dengan prinsip disain pesan dari Morrison, dkk (hal. 175-176) mengenai tehnik penyusunan isi dalam bentuk skema teks (text's schema) dengan cara :

- lists of items or ideas

- comparisons or contrasts

- temporal sequences

- cause-and-effect structures, or explanations

- definitions and example structures.

Prinsip tersebut di atas dapat diterapkan secara simultan dalam satu alur belajar berikut berlaku untuk penyusunan learning object. Dalam hal ini, yang patut diingat adalah falsafah penyusunan materi ajar yaitu 'membelajarkan melalui web atau online'. c. Menyusun peta konsep (concept mapping) bagi penggalan materi yang rumit dan kontekstual Sebagai contoh, subtopik Perumusan Tujuan Pembelajaran termasuk dalam kategori rumit, kontekstual dan sangat penting. Untuk itu, peta konsep dibuat seperti ilustrasi berikut. Peta konsep membantu pengajar untuk menentukan pemilihan tehnik penyajian yang akan dipilih. Dalam hal ini, seperti pengertian, dan fungsi masing-masing dapat dijadikan learning object dalam bentuk teks. Sedangkan kriteria, yang menjelaskan tentang tehnik merumuskan tujuan pembelajaran disajikan dalam bentuk powerpoint (gambar bingkai penyajian) yang selanjutnya diubah menjadi learning object. Begitu seterusnya sampai dengan pembahasan Tujuan Pembelajaran tersebut tuntas.

d. Paradigma (digital) pendidikan yang dianut adalah paradigma teachercentered. Paradigma teachercentered diterapkan dalam kerangka dosen sebagai course manager bertugas untuk mengatur alur belajar serta menentukan isi atau learning objects. Penerapan teacher-centered juga mempertimbangkan perilaku belajar mahasiswa yang masih bertumpu pada kehadiran dan upaya dosen untuk mengikuti perkuliahan.

e. Berdasarkan teori pemanfaatan media pembelajaran dari Bretz, maka penyajian isi dalam website bagi model belajar hibrada adalah sebagai subsistem atau pengayaan. Fungsi subsistem berarti bahwa penyajian materi secara online hanya salah satu bagian dari seluruh kegiatan perkuliahan yang sebagian besar berbasis kampus. Materi kuliah yang disampaikan online termasuk dalam ragam pengetahuan kognitif. 
Satu fungsi yang tidak dapat dilakukan adalah menerapkan model e-learning secara utuh, yaitu sebagai sistem pembelajaran, yakni $100 \%$ mengandalkan penyajian materi secara online. Jurusan KTP FIP UNJ ini merupakan universitas konvensional yang basisnya adalah kegiatan belajar di kampus. Model belajar hibrida dikembangkan untuk mengatasi salah satu kendala yaitu jumlah mahasiswa yang besar dan dipandang tidak ideal untuk berada dalam satu ruang kelas.

f. Menerapkan prinsip kaizen atau continuous improvement dalam rangka peningkatan mutu perkuliahan. Setiap saat course manager harus selalu siap menambah, memperbaiki, mengurangi dsb untuk menyediakan materi yang up to date

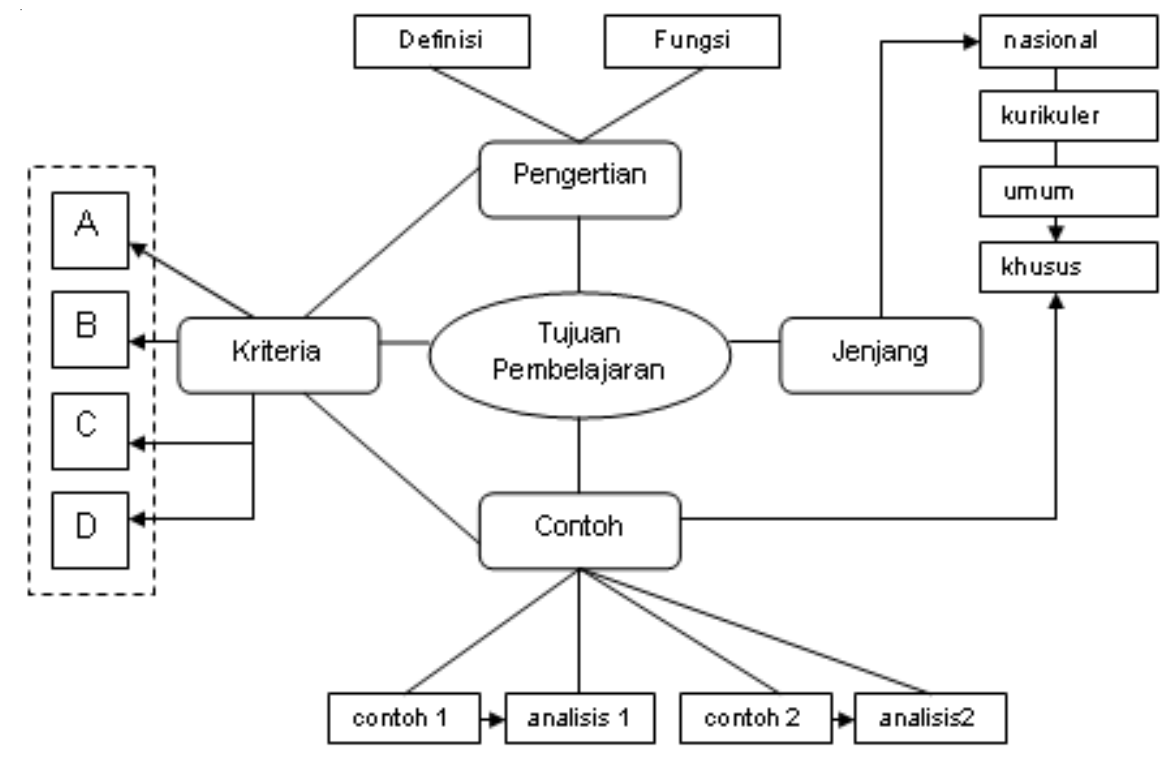

Gambar 15. Contoh Peta Konsep tentang Tujuan Pembelajaran

Learning Path

tujuan pembelajaran

Rumusan tujuan pembelajaran mengalami perubahan karena pengetahuan tentang hasil belajar sudah dikajulang oleh para pakar. Krathwohl, dkk menambarkan adarya kemampuan metakognitf serta aspek menciptakan (create) dalam rumusan tujuan pembelajaran.

Module
pengetahuan awal
pengetahuan awal menjadi modal dasar dalam merumuskan tujuan pembelajaran. Dengan demikian, kita perlu
mengukur kemampuan awal peserta didik.

pertama kali pertemuan di kelas, semua peserta didik perlu diukur kemampuannya. Pengukuran dapat dilakukan dengan memberikan pretes.

Tehnik Merumuskan Tujuan Khusus

]contoh TIK swf.swf

Dteknk Rumusan Tujuan Pembelajaran.swf

Tujuan Khusus dirumuskan dengan lengkap agar kondisi dan situasi belajar yang sesuai dapat dideteksi dan ditelusuri. Jika ada kegagalan, maka perbaikan menjadi lebih mudah diketahui.

Learning path progression :

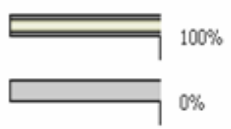




\section{Optimalisasi Peran Pengajar}

Seperti telah disebutkan beberapa kali dalam tulisan ini, pengajar atau dosen berperan besar dalam mengembangkan model e-learning. Dosen bukan hanya menyajikan materi secara langsung dan tatapmuka di kelas. la juga sebaiknya bersedia untuk menyisihkan waktu, tenaga dan pikiran untuk duduk di depan komputer dalam waktu yang relatif lama. Peran pengajar dalam e-learning dapat dijelaskan sebagai beirkut:

- sebagai course manager

la adalah course manager sekaligus creator proses belajar maya. Profesi dosen menjadi lebih sulit dan rumit karena ia tidak dapat mewakilkan penyajian online kepada seseorang untuk mengirim (upload) materi. Pengajar dalam pembelajaran maya diuntungkan oleh beberapa hal, diantaranya adalah keluwesan waktu dan lokasi. Selain itu, kemampuan untuk memanfaatkan jaringan internet sebenarnya mencerminkan kemampuan lain yang harus dimiliki oleh seorang dosen. la harus memperbaiki serta mengisi sendiri alur belajar dalam LCMS. Jika ada perubahan, maka ia harus langsung berselancar di dunia maya. Sebagai course manager, ia dituntut untuk mampu beradaptasi dengan cepat atas teknologi yang terus berkembang. la harus mampu mengoperasikan LCMS itu sendiri. Pengorbanan lain adalah ketelatenan serta waktu yang harus dihabiskan sewaktu menulis dan mengisikan materi ke dalam LCMS.

- sebagai katalis (catalyst) sekaligus agen pembaharu (change agent) Seorang katalis bekerja untuk menjaring dan menjembatani proses akulturasi yang terjadi dimana dia berada. Dosen sebagai katalis adalah dosen yang mampu menterjemahkan kegiatan belajarmengajar dengan bertatapmuka langsung menjadi suatu kegiatan belajar-mengajar maya. Pola pikir yang ditanamkan kepada para mahasiswa adalah perilaku belajar self-directed. Perilaku self-directed termasuk proses akulturasi dari perilaku belajar yang disuapi, diarahkan oleh dosen menjadi perilaku pengelola belajar sendiri.

Sebutan mahasiswa cenderung dicerna sebagai peserta didik belajar dan datang ke kampus untuk mengikuti perkuliahan. Pergeseran lokasi belajar (penyajian materi) di ruang kelas menjadi tayangan online dan dapat dilakukan dimana saja masih sulit ditanamkan pada mahasiswa yang memiliki pola pikir konvensional. Berdasarkan pengamatan dalam matakuliah Disain Pembelajaran, para mahasiswa masih belum terbiasa belajar sendiri. Budaya belajar ke kampus dan ada dosen di kelas masih tetap melekat. Untuk itu, dosen ditantang untuk menyebarkan gagasan pergeseran lokasi belajar serta inovasi penyajian materi ini setahap demi setahap.

\section{- sebagai dosen}

Sebutan dosen digunakan untuk merujuk segala sesuatu pekerjaan yang masih tetap harus dilakukan oleh dosen dengan mengandalkan kehadiran secara fisik dan pelaksanaan pekerjaan manual. Membimbing skripsi, menilai, menyusun kontrak perkuliahan hanyalah beberapa tugas saja yang masih harus dilakukan secara manual. Interaksi antar individu, antara dosen dengan mahasiswanya, masih tetap dilaksanakan namun dalam porsi yang lebih efektif. Pengalihan sebagian tugas ke hypermedia, diterapkan agar tugastugas lain yang belum tertangani secara manual dapat diselesaikan dengan baik.

\section{Manfaat dan Keterbatasan Model e-learning}

a. Manfaat

- Penyelenggaran model elearning bagi Jurusan KTP FIP UNJ dapat membantu mengatasi 'jumlah' mahasiswa yang besar 
dengan cara menyelenggarakan belajar hibrida. Jurusan KTP FIP UNJ sebagaimana universitas konvensional, tetap melaksanakan proses belajar mengajar di kelas. Efektifitas PBM dapat dicapai dengan cara memilah materi kuliah yang sesuai untuk PBM dan secara online.

- Penyajian materi online dapat pula dimanfaatkan untuk program pengayaan yang berlangsung setiap waktu.

- Materi online dapat diperbaiki, dikembangkan setiap saat tanpa dosen harus selalu datang ke kampus.

- Sarana website dapat dimanfaatkan untuk berkomunikasi dengan mahasiswa.

b. Keterbatasan

- Jurusan KTP FIP UNJ terikat dalam suprasistem UNJ dan Ditjen DIKTI, serta Fakultas IImu Pendidikan. Dengan sendiri, laju pemanfaatan dapat terkendala. Sebagai contoh, kelancaran kerja jaringan di UNJ berdampak terhadap seluruh kegiatan terkait dengan e-learning.

- Keterbatasan kemampuan kampus untuk menyelenggarakan wi-fi menyebabkan terhambatnya faktor teknis jaringan.

- Ketersediaan SDM pengelola, dosen dan web administrator terbatas. Penyajian materi online memerlukan kemampuan khusus sebagai dosen. Dengan sendirinya tuntutan kemampuan terhadap seorang dosen menjadi berlapis-lapis, yaitu menguasai disiplin ilmu, disain pembelajaran sekaligus menjadi creator, course manager bagi model e-learning.

- model e-learning termasuk mahal, tidak hanya berdasarkan pembiayaan, namun waktu serta kemampuan dosen dan mahasiswa dalam pemanfaatanya.

\section{Hak Cipta}

Sama halnya dengan perdebatan antara LMS dan LCMS, hak cipta juga masih mejadi isu hangat dalam pembelajaran online. Simonson, dkk dan Dabbagh \& Bannan-Ritland telah mengingatkan produsen (LCMS, materi ajar) untuk kemungkinan penggunaan secara tak terhingga/terbatas. Selain itu, mereka juga mengingatkan para pengguna untuk menghormati hak cipta yang ada pada produsen. Hak cipta ini berlaku bagi segala sesuatu yang diunduh secara bebas atau karya kreatif yang dikomersialkan. Beberapa hal yang perlu diperhatikan diantaranya adalah :

a. Prinsip fair use

Prinsip fair use merujuk pada penggunaan secara terbuka untuk sebagian, seluruhnya, atau sepenggal dari piranti lunak, karya tulis/ilmiah, atau karya kreatif lain untuk digunakan oleh seseorang, suatu organisasi, suatu negara dan seterusnya dengan menyebutkan sumber sebagai bukti pengakuan (acknowledgment) bahwa karya tersebut digunakan baik untuk tujuan nirlaba atau komersial. Pengakuan ini adalah bentuk penghargaan atas karya orang/pihak lain yang bermanfaat untuk kepentingan bersama. Terkait dengan materi ajar, karya suatu materi ajar yang disebar melalui suatu platform, tetap menjadi milik si pengisi atau penulis, namun dapat dimanfaatkan oleh siapa saja dengan pengakuan terhadap penulis.

b. Tenggat waktu (duration)

Terkadang, waktu menjadi patokan penggunaan karya kreatif tertentu. Dalam hal ini, pengguna diwajibkan untuk langsung berkomunikasi dengan produsen karya kreatif dan mengikuti persyaratan yang telah ditentukan oleh produsen tersebut. Untuk karya kreatif pembelajaran biasanya perlu menjabarkan prosedur penggunaan serta tujuan penggunaan dari karya kreatif itu. 
c. Ranah Publik

Produsen karya kreatif harus menyadari bahwa karya yang disebar secara online sudah dipastikan menjadi terbuka dan dapat dimanfaatkan oleh siapa saja. Untuk itu, ia perlu menyiapkan perangkat penggunaan untuk publik serta prosedur pemantauan penggunaannya.

\section{KESIMPULAN DAN SARAN}

\section{Kesimpulan}

Model e-learning telah menjadi simbol globalisasi dan industrialisasi dunia pendidikan. Model ini dapat dilaksanakan dengan memanfaatkan suatu platform LCMS untuk menyajikan materi secara online. Dalam pengisian dan penyusunan LCMS, beberapa kaidah disain pembelajaran diantaranya adalah :

- memaknai perangkat menulis yang tersedia dalam LCMS dalam konteks disain pembelajaran, bukan sebagai kemampuan perangkat lunak online yang tersedia dalam komputer;

- analisis topik yang mengacu pada pola sistem diterapkan dengan penyesuaian terhadap tujuan pembelajaran, peserta didik, kemampuan prasyarat serta sifat materi ajar atau topik itu sendiri.

- alur penyajian : linear, bercabang, atau hypercontent,

- disain pesan : pengembangan materi ajar dengan menyelaraskan penggalan (chunk) dengan prinsip disain pesan tertentu agar menjadi penggalan materi terkecil, khusus, namun tetap bermakna dan mengandung aspek kemampuan yang sesuai.

- hak cipta menjadi sangat penting karena pengguna atau peserta didik, jika disajikan secara tak terhingga, maka materi ajar tersebut dapat dikaji dan dimanfaatkan oleh siapa saja. Aturannya adalah pengakuan terhadap kreatifitas penulis, perancang, atau pihak yang telah memproduksi materi ajar tersebut.

\section{Saran}

Mengacu pada keismpulan di atas, maka penyelenggaraan model e-learning, khususnya di Perguruan Tinggi hendaknya memperhatikan dan atau mempertimbangkan beberapa hal sebagai berikut:

- sebelum memanfaatkan suatu LCMS tertentu hendaknya memahami betul fasilitas/fitur LCMS khususnya yang terkait dengan desain pembelajaran. Setiap LCMS memiliki fitur yang kurang lebih mirip tapi agak memiliki perbedaan, sehingga penting untuk dipahami dengan seksama terlebih dahulu agar dapat digunakan secara optimal untuk tujuan pembelajaran yang diinginkan terjadi.

- Analisis topik hendaknya dilakukan dengan seksama mengacu pada tujuan pembelajaran, karakteristik peserta didik, sert5a difat dari materi itu sendiri.

- Alur penyajian hendaknya dirancang sedemikian rupa agar memungkinkan terjadinya self-directed learning dengan mengoptimalkan prinsip branching dan hypercontent.

- Dalam pengembangan materi (konten), hendaknya memperhatikan prinsip desain pesan (message design).

- Sebagai aktifitas ilmiah, maka hak cipta dan hak kekayaan intelektual penting diperhatikan baik ketika memanfaatkan karya orang lain (eksternal) maupun ketika memanfaatkan karya sendiri (internal).

\section{DAFTAR PUSTAKA}

Tozman, Reuben. "Another New Paradigm for Instructional Design". www.astd.org.

Oristian, Katie. "Online Learning Modules". http://coe.sdsu.edu/articles/learningmodules/ start.htm.

Greenberg, Leonard. "LMS and LCMS : What's the Difference?".

http://www.learningcircuits.org/2002/dec2002/ 
greenberg.htm.

Checkpoint E_Learning Journal, "Insight into Learning Content Management Systems : an Interview with Stephen Shaw".

Mortimer, Lori, "(Learning) Objectss of Desire : Promise and Practicality". www.astd.org.

Bryan Chapman, "LCMS" : An IDC White Paper. Dabbagh, Nada \& Brenda Bannan-Ritland (2005).

Online Learning : Concepts, Strategies, and Application. Upper Saddle River, NJ : Pearson (Merrill - Prentice Hall, Inc).

Fleming, Malcolm and W. Howard Levie (1978). Instructional Message Design. Englewood Cliffs, NJ : Educational Technology Publ.

Holmes, Bryn and John Gardner (2006). ELearning : Concepts and Practice. London, UK : Sage Publ.

Morrison, Gary R, Steven M. Roos, Jerrold E. Kemp (2007). Designing Effective Instruction $\left(5^{\text {th }}\right.$ ed). Hoboken, NJ : John Wiley \& Sons, Inc.
Prawiradilaga, Dewi Salma (2007). Prinsip Disain Pembelajaran, Jakarta : Kencana, PT Prenada Media Group.

Januszewski, Alan and Michael Molenda (2008). Educational Technology : A Definition with Commentary. New York : Lawrence Erlbaum Associates - Taylor \& Frances Group.

Schlosser, Lee Ayres, and Michael Simonson (2006). Distance Education: Definition and Glossary of Terms ( $2^{\text {nd }}$ ed). Greenwich, CONN. : Information Age, Pub.

Simonson, Michael, Sharon Smaldino, Michael Albright, and Suzan Zvacek (2006). Teaching and Learning at a Distance : Foundations of Distance Education ( $3^{r d}$ Ed.).. Upper Saddle River, NJ : Pearson (Merrill - Prentice Hall, Inc). 